SEEING AND BEING SEEN 
THIS PAGE INTENTIONALLY LEFT BLANK 


\section{Seeing and Being Seen}

THE Q'EQCHI' MAYA OF LIVINGSTON, GUATEMALA, AND BEYOND

Hilary E. Kahn 
A version of Chapter 8 and sections of Chapter 4 previously appeared in 2001 as "Respecting Relationships and Día de Guadalupe: Q'eqchi' Mayan Identities in Livingston, Guatemala." Journal of Latin American Anthropology 6(1):2-29.

A version of Chapter 9 previously appeared in 2003 as "Traversing the Q'eqchi' Imaginary: The Conjecture of Crime in Livingston, Guatemala." In Crime's Power: Anthropologists and the Ethnography of Crime, edited by Stephanie Kane and Phillip Parnell, New York: Palgrave Macmillan, 2003, 33-54.

Copyright (C) 2006 by the University of Texas Press All rights reserved Printed in the United States of America First edition, 2006

Requests for permission to reproduce material from this work should be sent to:

Permissions

University of Texas Press

P.O. Box 7819

Austin, TX 78713-7819

www.utexas.edu/utpress/about/bpermission.html

(2) The paper used in this book meets the minimum requirements of ANSI/NISO Z39.48-1992 (R1997) (Permanence of Paper).

LIBRARY OF CONGRESS CATALOGING-IN-PUBLICATION DATA

Kahn, Hilary E., 1966-

Seeing and being seen : the Q'eqchi' Maya in Livingston, Guatemala, and beyond / Hilary E. Kahn. - 1st ed.

p. $\quad \mathrm{cm}$.

Includes bibliographical references and index.

ISBN-13: 978-0-292-71348-2 (cl. : alk. paper)

ISBN-10: 0-292-71348-7

ISBN-13: 978-0-292-71455-7 (pbk. : alk. paper)

ISBN-10: 0-292-71455-6

1. Kekchi Indians-Guatemala-Livingston-History.

2. Kekchi Indians - Guatemala-Livingston-Ethnic identity.

3. Kekchi Indians - Guatemala-Livingston-Social conditions.

4. Video recording in ethnology-Guatemala-Livingston.

5. Motion pictures in ethnology-Guatemala-Livingston.

6. Indians in motion pictures. 7. Livingston (Guatemala)-Social life and customs. I. Title.

F1465.2.K5K34 2006

$305.897^{\prime} 42072813-\mathrm{dc} 22$ 
This book is dedicated to my son Noah Alexander Kahn Johnson and godson Eduardo Martín Xol Chub for linking us all through time and space. 
THIS PAGE INTENTIONALLY LEFT BLANK 